\title{
Muscular Dystrophy-Dystroglycanopathy (Congenital with Brain and Eye Anomalies) Type A, 6
}

National Cancer Institute

\section{Source}

National Cancer Institute. Muscular Dystrophy-Dystroglycanopathy (Congenital with

Brain and Eye Anomalies) Type A, 6. NCI Thesaurus. Code C126743.

An autosomal recessive muscular dystrophy caused by mutations in the LARGE gene. It is associated with characteristic brain and eye malformations, profound mental retardation, and death usually in the first years of life. 